\title{
Mutation Breeding in Tomato: Advances, Applicability and Challenges
}

\author{
Juhi Chaudhary ${ }^{1}$, Alisha Alisha ${ }^{2}{ }^{(}$, Vacha Bhatt ${ }^{2}$, Sonali Chandanshive ${ }^{2}$, Nirbhay Kumar ${ }^{2}$, \\ Zahoor Mir ${ }^{3}$, Ashwini Kumar ${ }^{4}$, Satish K. Yadav ${ }^{5}$, S. M. Shivaraj ${ }^{6}$, Humira Sonah ${ }^{2, *}$ \\ and Rupesh Deshmukh 2,*(D) \\ 1 Department of Biology, Oberlin College, Oberlin, OH 44074, USA; juhi.chaudhary@gmail.com \\ 2 National Agri-Food Biotechnology Institute (NABI), Mohali, Punjab 140308, India; \\ alishaalisha001@gmail.com (A.A.); vacha.biotech@gmail.com (V.B.); \\ chandanshivesonali444@gmail.com (S.C.); nirbhay.kumar@imsuc.ac.in (N.K.) \\ 3 National Research Center on Plant Biotechnology, New Delhi, Delhi 110012, India; zahoorbio@gmail.com \\ 4 Division of Plant Pathology, ICAR-IARI, New Delhi, Delhi 110001, Inida; ashwinikumar1500@gmail.com \\ 5 National Bureau of Plant Genetic Resources, New Delhi, Delhi 110012, India; satish.yadav1@icar.gov.in \\ 6 Faculté des sciences de l'agriculture et de l'alimentation (FSAA), Université Laval, \\ Quebec, QC G1V 0A6, Canada; sraj100@gmail.com \\ * Correspondence: biohuma@gmail.com (H.S.); rupesh0deshmukh@gmail.com (R.D.); \\ Tel.: +91-9650792638 (R.D.)
}

Received: 1 April 2019; Accepted: 11 May 2019; Published: 14 May 2019

\begin{abstract}
Induced mutagenesis is one of the most effective strategies for trait improvement without altering the well-optimized genetic background of the cultivars. In this review, several currently accessible methods such as physical, chemical and insertional mutagenesis have been discussed concerning their efficient exploration for the tomato crop improvement. Similarly, challenges for the adaptation of genome-editing, a newly developed technique providing an opportunity to induce precise mutation, have been addressed. Several efforts of genome-editing have been demonstrated in tomato and other crops, exploring its effectiveness and convenience for crop improvement. Descriptive data compiled here from such efforts will be helpful for the efficient exploration of technological advances. However, uncertainty about the regulation of genome-edited crops is still a significant concern, particularly when timely trait improvement in tomato cultivars is needed. In this regard, random approaches of induced mutagenesis are still promising if efficiently explored in breeding applications. Precise identification of casual mutation is a prerequisite for the molecular understanding of the trait development as well as its utilization for the breeding program. Recent advances in sequencing techniques provide an opportunity for the precise detection of mutagenesis-induced sequence variations at a large scale in the genome. Here, we reviewed several novel next-generation sequencing based mutation mapping approaches including Mutmap, MutChromeSeq, and whole-genome sequencing-based mapping which has enormous potential to accelerate the mutation breeding in tomato. The proper utilization of the existing well-characterized tomato mutant resources combined with novel mapping approaches would inevitably lead to rapid enhancement of tomato quality and yield. This article provides an overview of the principles and applications of mutagenesis approaches in tomato and discusses the current progress and challenges involved in tomato mutagenesis research.
\end{abstract}

Keywords: genome-editing; mutagenesis approaches; mutmap; mutation breeding; next generation sequencing tools; tomato 


\section{Introduction}

Tomato (Solanum lycopersicum L.) is one of the most popular cultivated vegetable crops worldwide. It is a model plant of the Solanaceae family because of its short life cycle, simple diploid genome, availability of efficient tools for plant transformation, and available genome sequence [1,2]. The global demand for tomato increased tremendously in recent years due to its diverse utility in raw, cooked, and processed food as well as its nutritional value. In addition, the changes in climatic conditions and human population growth etc. are posing the biggest challenge to sustain the supply worldwide. This necessitates the sustainable production of nutritious and high-yielding tomato cultivars considering the rapidly changing environmental conditions. The development of high yielding cultivars with improved fruit quality and tolerance against abiotic and biotic stresses is challenging, mostly due to the narrow genetic diversity existing in the cultivated tomatoes. To overcome the bottleneck, efforts are being made to explore wild species like Solanum pimpinellifolium (which has only $0.6 \%$ nucleotide divergence from cultivated tomato) [3]. However, introgression of the wild genome considerably hampers the well optimized high-yielding genetic background of the commercial tomato cultivars. In addition, introgression breeding is a time-consuming process. Besides, crossing incompatibility of cultivated varieties with wild species is also a limitation. In this regard, mutation breeding provides one of the most promising option to broaden the genetic diversity and achieve rapid crop improvement. Induced mutagenesis has been performed in a number of crop species including rice [4], banana [5], and watermelon [6].

The change in climatic conditions are unpredictable, therefore there is a need for new varieties to be developed regularly for sustainable production. Since the spontaneous mutation rate is very slow, induced mutation is necessary to enhance the rate of genetic diversity so that breeders can exploit the diverse varieties in plant breeding programs. In addition, multiple-trait mutants can be isolated by mutation breeding and the chances of survival of mutant varieties are much higher under rapidly fluctuating climatic conditions. Mutagenesis is an efficient process of generating mutation, which can occur spontaneously or can be induced by a mutagen. Several efficient methods to induce genetic mutations have been developed which are broadly classified as physical and chemical mutagenesis based on the nature of mutagenic agent. Mutagens provide better chances to obtain desirable phenotypic variation and they are also used to study genotypic variations associated with phenotypes as well as annotation of gene function. A number of studies on mutagenesis in tomato have been performed to discover the function of genes associated with economically important traits like fruit quality (Table 1). Several physical and chemical mutagenic agents like gamma rays and ethyl methane sulfonate (EMS) have been used in tomato for induced mutagenesis (Table 1). Numerous genetic resources of tomato mutant lines have been generated worldwide by using EMS, gamma-rays and fast neutron mutagenesis. Additionally, several resources to find a variety of tomato mutants such as LycoTILL for Red Setter, 'Genes that make tomatoes' for M82, and TOMATOMA for Micro-Tom, are publicly available. The conventional physical and chemical mutagenesis approaches induce random mutations in the genome. Hence, it leads to several non-target mutations, so it is difficult to obtain the desired one. However, newly developed mutagenesis approaches based on the genetic engineering tools are very specific to alter the target gene. Currently, the most commonly used approach of targeted mutagenesis is gene editing by CRISPR/Cas9 and TALENs due to the availability of genomic sequences of S. lycopersicum and its wild relative S. pimpinellifolium $[7,8]$.

Generating a large mutant population and subsequent screening for phenotypic changes is comparatively easier than the identification of casual variation induced by the mutagenesis. Conventionally, linkage analysis using molecular markers and segregating the population developed from the mutant line and genotype with diverse genetic background have been used for the mapping of the casual variation. Even after genetic mapping, extensive efforts are required to pinpoint the casual variation. Fortunately, the entire genome sequence is available for tomato, which provides the basis for the mapping and identification of variations. The whole genome sequencing data have led to the identification of millions of single nucleotide polymorphisms (SNPs) and indels (insertions and 
deletions) in tomato genotypes and mutant lines. Considering the development in the high-throughput next generation sequencing (NGS) technology, several novel approaches have been developed for the identification of mutations in the mutagenized populations. MutMap (mapping-by-sequencing) and MutChromSeq approach are the notable examples where NGS technology is used to identify the casual variation induced by the mutagenesis. MutChromSeq helps to identify the candidate genes in shortest time and has been employed successfully in barley and wheat. However, it has not been utilized in tomato for the identification of candidate genes. In this review, we discuss the various induced mutagenesis approaches, their utility for tomato improvement, available mutant resources and mutation mapping methods to provide an insight into the advances in plant mutagenesis research.

Table 1. List of significant studies describing induced mutagenesis efforts performed in tomato using different chemical and physical mutagens.

\begin{tabular}{|c|c|c|c|c|c|}
\hline Tomato Cultivar & Mutagen & $\begin{array}{l}\text { Concentration/ } \\
\text { Dose }\end{array}$ & $\begin{array}{l}\text { Number of } \\
\text { Mutants }\end{array}$ & Reason & Reference \\
\hline Moneymaker & $\begin{array}{l}\text { EMS (ethyl } \\
\text { methane sulfonate) }\end{array}$ & $60 \mathrm{mM}$ & NA & Isolated $A d h 1$ null mutant of tomato & [9] \\
\hline M82 & EMS & $0.5 \%$ & 2552 & For functional genomic studies & [10] \\
\hline M82 & Fast neutron & $15 \mathrm{~Gy}$ & 865 & For functional genomic studies & [10] \\
\hline $\begin{array}{l}\text { Lycopersicon } \\
\text { esculentum Mill. }\end{array}$ & Sodium azide & $4 \mathrm{mM}$ & $31.07 \%$ & To improve the variety & [11] \\
\hline $\begin{array}{l}\text { Lycopersicon } \\
\text { esculentum Mill. }\end{array}$ & EMS & $1.5 \%$ & 16 & For resistance to Orobanche ramosa $\mathrm{L}$. & {$[12]$} \\
\hline Micro-Tom & $\begin{array}{l}\text { Gamma-ray } \\
\text { irradiation }\end{array}$ & 300 Gy & 6347 & For functional genomics studies & [13] \\
\hline Red Setter & EMS & $1 \%$ & 4500 & To develop Red Setter TILLING platform & {$[14]$} \\
\hline Red Setter & EMS & $0.7 \%$ & 8500 & To develop Red Setter TILLING platform & [14] \\
\hline M82 & EMS & & 4759 & For resistance to Potyvirus & [15] \\
\hline Micro-Tom & EMS & $1 \%$ & NA & For forward and reverse genetic studies & [1] \\
\hline
\end{tabular}

\section{Induced Mutagenesis}

\subsection{Chemical Mutagenesis}

Chemical mutagenesis is one of the most efficient and convenient approaches used in diverse plant species. In tomato, EMS and sodium azide have been used as chemical mutagens (Table 1). The EMS is the most widely used chemical mutagen in plants because of its high effectiveness at inducing point mutations and deletions in the chromosomal segments [12]. In tomato, EMS has been shown to produce both morphological variations and desired trait improvements like disease resistance, fruit quality, and male sterility $[16,17]$. In several cases, EMS mutagenesis found efficient where other conventional tomato breeding approaches are not feasible, for instance, in the case of Broomrape (Orobanche ramosa L.) a wide parasitic weed responsible for the large economic losses in tomato yield [12]. No resistance source is known therefore to overcome the limitation, EMS mutagenesis has been used and after the multiple screening of offspring from several generations six resistance lines against the Broomrape have been developed [12]. Similarly, EMS mutagenesis has been used to develop resistance against potyvirus, a widespread destructive virus for tomato. It has been shown that mutation in translation initiation factors mainly eukaryotic initiation factor $4 \mathrm{E}$ (eIF4E) plays a role in tomato resistance to the two potyviruses namely Potato virus Y (PVY) and Tobacco etch virus (TEV). The recessive resistance gene pot-I encodes eIF4E 1 protein and the difference between resistance and susceptible proteins was found to be the substitution of four amino acids. So, mutagenesis of the M82 variety was performed with EMS and a mutant population was developed; subsequent screening identified the mutant line with a spliced variant of eIF4E 1 providing resistance to both the potyvirus strains in tomato [15].

Conventional mutation techniques helped in both forward as well as reverse genetic studies [18]. The reverse genetics tool, targeted induced local lesions in genomes (TILLING) has been developed to identify allelic variation of mutants efficiently [18]. The TILLING approach have been used to screen mutant population developed EMS and fast neutron mutant to enhance the genomics studies in tomato [14]. Efforts have been made to raise mutant populations from tomato cultivars Red Setter, 
TPAADASU, and Micro-tom using the EMS mutagen. Among different cultivars, a mutant population derived from Micro-tom has great importance since it is considered as a model plant due to its small size, fast growth and ease of transformation, and is being used in large-scale mutant screening [19]. Furthermore, TILLING platforms have been developed from these mutant populations which will surely facilitate the reverse genetics studies in tomato [1].

\subsection{Physical Mutagenesis}

Physical mutagens such as fast neutron and gamma rays produce vast amount genetic variability and have played a significant role in plant genetics studies. In tomato, physical mutagens including radiations like gamma rays and ionization with neutrons are frequently employed for mutagenesis (Table 1). For example, about 6000 Micro-Tom mutant lines were generated using gamma-rays irradiation. From this, around 24 morphological mutant lines and eight brix mutant lines were screened and QTL analysis revealed the involvement of two loci in the brix mutants which can be used to identify brix-regulating genes in tomato [13]. Similarly, fast neutron and other physical mutagens can be explored to induce beneficial variability in tomato for enhanced quality and yield. Besides, physical mutagens are not as popular as chemical mutagens mostly due to the requirement of specialized instruments, skilled staff and highly secure laboratories. Physical mutagens like gamma-irradiation produces severe genetic mutations due to large chromosomal deletions and reconstitution of chromosome [13].

Fast neutron mutagenesis is relatively new for plant science and the least explored approach [20]. However recent studies have shown the effectiveness and ease of reverse genetics using a fast neutron mutagenesis population. Fast neutron bombardment is used to generate deletions and chromosomal rearrangements in the genome randomly and hence employed for the identification and isolation of mutants in target genome [20,21]. The major fast neutron technique used in plants is Deletagene. In this method, fast neutrons are used to induce mutations in the seeds and the deletions produced are further analysed by polymerase chain reaction (PCR) using specific primers flanking the target genes [20,21].

\subsection{Insertional Mutagenesis}

Gene inactivation has been successfully employed in determining the function of unknown genes in several plant species. Inactivation of endogenous genes has been employed by introducing sense and antisense copies of a target gene; however, when the target locus is uncharacterized, insertional mutagenesis is considered the most convenient approach of gene inactivation [22,23]. The insertional mutagenesis is performed by using a DNA sequence (T-DNA, transposon or retrotransposon) to mutate and tag the gene, which can be studied by observing the mutated site using the tag as an identifier. Furthermore, a PCR-based approach, site-selected insertion (SSI), is used for detection of mutations in known genes by insertional inactivation. In this technique, two primers are designed, one specific for sequences in the target gene and another for sequences in the transposon, and amplification products are observed for genes with an insertion. This technique was successfully used to detect the transpositions that occurred in polygalacturonase (PG) and dihydroflavonol 4-reductase (DHFR) genes by Ds1 elements. It was shown that SSI and maize Ds elements significantly facilitate insertional mutagenesis in tomato [24]. In another study conducted by the same group, SSI was used to generate insertional mutations in $P G$ gene to delay fruit ripening in tomato. Among 4000 progenies screened for insertions in $P G$, five were found to be germinally transmitted $D s$ insertions and one among them revealed to have two $D s$ insertions. Around 1000-fold polygalacturonase reduction have been observed in these mutants. The Ds elements were further stabilized by eliminating transposase so that no genetic material is left in the PG gene and this could be exploited on a commercial scale to generate desired mutations in plants with no transgenic material [25]. Moreover, a significant number of studies have been performed for morphological and functional mutation induction by both transposons and T-DNA in tomato (Table 2). 
Table 2. Significant studies demonstrating use of insertional mutagenesis approach to induce mutations in tomato.

\begin{tabular}{|c|c|c|c|c|}
\hline $\begin{array}{c}\text { Tomato } \\
\text { Variety/Cultivar }\end{array}$ & Insertional Mutagen & Target Gene/s & $\begin{array}{l}\text { Transformation Method; } \\
\text { Vector }\end{array}$ & Reference \\
\hline cv. VF36 & $\begin{array}{l}\text { Dissociation } \\
\text { transposable element } \\
\text { with Ac3 }\end{array}$ & NA & $\begin{array}{l}\text { Agrobacterium-mediated; } \\
\text { pBH2 }\end{array}$ & [26] \\
\hline $\begin{array}{l}\text { cv. VFNT Cherry } \\
\text { (LA 1221) }\end{array}$ & $\begin{array}{l}\text { Maize transposable } \\
\text { element } D s 1\end{array}$ & $\begin{array}{l}\text { polygalacturonase } \\
\text { (PG) and } \\
\text { dihydroflavonol } \\
\text { 4-reductase } \\
\text { (DHFR) genes }\end{array}$ & $\begin{array}{l}\text { Agrobacterium-mediated; } \\
\text { pMON200 }\end{array}$ & [24] \\
\hline $\begin{array}{l}\text { VFNT Cherry and } \\
\text { New Yorker }\end{array}$ & Chimeric Ds element & Lc & $\begin{array}{l}\text { Agrobacterium-mediated; } \\
\text { pAL69 and pAL144 }\end{array}$ & {$[27]$} \\
\hline $\begin{array}{l}\text { VF36 (LA490) and } \\
\text { VFNT Cherry (LA1221) }\end{array}$ & $\begin{array}{l}\text { Ac transposase and a } \\
\text { chimeric Ds element }\end{array}$ & PG & $\begin{array}{l}\text { Agrobacterium-mediated; } \\
\text { pVCY1601 (VFNT Cherry) }\end{array}$ & [25] \\
\hline cv. Micro-Tom & $\begin{array}{l}\text { Activation-tagging } \\
\text { technology }\end{array}$ & ant1 & $\begin{array}{l}\text { Agrobacterium-mediated; } \\
\text { pSKI015 }\end{array}$ & [28] \\
\hline LA0315 and LA3899 & Rider transposon & SlMBP21 & $\begin{array}{l}\text { Agrobacterium-mediated; } \\
\text { pGEM-T Easy vector }\end{array}$ & [29] \\
\hline
\end{tabular}

\subsection{Mutagenesis by Antisense Approach}

Antisense technology is performed to 'knock down' the genes in order to study their function. It is performed in three different ways; one is by binding the single stranded antisense complementary nucleic acid sequence to target sense mRNA to block its translation while another is by binding catalytically active oligonucleotides like ribozymes which degrade specific RNA sequences. The third method is by RNA interference in which small interfering RNA (siRNA) helps in the cleavage of RNA by formation of RNA induced silencing complex (RISC). In tomato, several studies have been performed using antisense approach, for example, the entire (e) locus which is known to control leaf morphology and responsible for the conversion of compound leaf morphology to simple leaves. Research has indicated that SIIAA9 is involved in tomato fruit development and leaf morphogenesis. The antisense mutagenesis approach was utilized to generate transgenic plants against SIIAA9 gene to understand the mechanism of compound leaf conversion. The leaf morphology of transgenics and entire locus mutants were found to be similar and no functional redundancy was found for the SIIAA9 gene in tomato. Additionally, a single-base cytosine deletion was found in coding region of SIIAA9 of entire mutants and mapping analysis revealed that both SIIAA9 and e genes were located on chromosome 4 [30].

Tomato breeders use rin (ripening inhibitor) mutation to reduce the softening of fruits. This mutation produced firm fruits with delayed ripening effects but decreased nutritional value, color and flavor of the tomato. Nonetheless, the tomato genome sequencing helped to find a number of genes regulating the ripening process and PL was found to be one of the enzymes involved in the change of texture in the tomato fruits. Therefore, in an attempt to delay the ripening of fruits, cv. Ailsa Craig was chosen. Furthermore, real time expression analysis revealed the expression of five PL genes, but one was found to be highly expressed and was selected as a target. So, RNAi construct was made against this gene and the transgenic tomato fruits obtained showed improved shelf life of storage for 14 days at $20^{\circ} \mathrm{C}$. Furthermore, silencing this gene improved the fruit firmness without affecting color, yield, weight, taste, aroma or total soluble solids [31]. In another study, silencing the PL gene by antisense inhibition in tomato has been reported to play an important role in fruit softening and pathogen resistance. A total of 22 PLs were identified in tomato and silencing of dominantly expressive gene SIPL (Solyc03g111690) resulted in enhanced fruit firmness as well as pathogen-resisting ability [32]. In conclusion, the use of the antisense approach has significantly enhanced the understanding of tomato fruit development and ripening mechanism. 


\subsection{Mutagenesis by Genome-Editing Approaches}

The ability to precisely edit genomes is a promising approach for advancing both basic and applied plant research. Recently, the development of sequence-specific DNA nucleases has been widely used for targeting specific genes to improve the productivity of important crop plants. Tomato is reported to be an ideal crop for genome editing in plants due to the availability of its genome sequence, ease of transformation and its diploidy nature [7,33-35].

The three principle genome-editing techniques that are used to target genes in DNA specific manner include zinc finger nucleases (ZFNs), transcription activator like effector nucleases (TALENS) and clustered regularly interspaced short palindromic repeats (CRISPR)/CRISPR-associated9 (Cas9) endonuclease.

\subsection{Genome Editing by Zinc Finger Nucleases (ZFNs)}

Zinc finger nucleases (ZFNs)-based genome editing is one of the primitive technologies which makes it possible to perform precise site-specific mutations [36]. The ZFNs form dimmers which recognize a specific target site and make a double-strand DNA break [36]. Subsequently, the endogenous DNA repair system act on the resultant double-strand DNA break to repair it by non-homologous end joining (NHEJ) or a homology-directed (HR) repair mechanism. At the target site, the repair mechanism leads to variations like insertions, deletions and single nucleotide polymorphisms (SNPs). The ZFN approach have been used in several plant species including tomato [37]. In a seminal study by Hilioti et al. (2016), the effectiveness of the ZFN approach was shown to create a variation in a LEAFY-COTYLEDON1-LIKE4 (L1L4) gene [37]. Subsequent development in other convenient genome-editing approaches as described below, the use of ZFN has become less frequent.

\subsection{Genome Editing by Transcription Activator-Like Effector Nucleases (TALENs)}

Transcription activator-like effector nucleases (TALENs) are composed of a free designable DNA, and have been successfully employed for specific gene mutation in many plant species including Arabidopsis, Brachypodium, barley, rice, tobacco, wheat, and soybean. The first successful report on gene editing in tomato by TALENs was reported in 2014 [8]. DELLA proteins are reported to be negative regulator of GA signaling and PROCERA (PRO) is the only reported DELLA gene in tomato. Previous reports to determine the role of PRO in GA signaling by missense mutation in the gene resulted in partial loss of activity. Therefore, targeted mutagenesis of PRO by TALENs was performed by Lor, Starker, Voytas, Weiss and Olszewski [8]. About $15 \%$ of the plants carried pro alleles and these mutants showed increased levels of GA. In addition, the mutant plants showed altered phenotypes like long internode length, smooth leaf margins and light green vegetation. A truncated PRO protein was produced due to frame-shift mutations and these mutations were also showed to be heritable [8]. Another report by Čermák et al. (2015) compared genome editing efficiency of TALENS and CRISPR/Cas9 approaches in tomato by targeting Anthocyanin mutant 1 (ANT1) gene. In this study, geminivirus replicons were used to create mutations and two-thirds of insertions were found to be precise without any unexpected sequence modifications in the tomato genome [38]. Hence, studies demonstrated TALENs as an efficient tool for creating targeted mutations in tomato.

\subsection{Gene Editing by CRISPR/Cas9}

Until 2013, ZFNs and TALENs were used for the precise genome-editing. Both of these methods have become least preferred choice after the development of more efficient and easier method like CRISPR/Cas9-based genome editing. The CRISPR/Cas9 strategy is considered a ground-breaking genome editing tool which has been successfully applied in many model and crop plants including tomato (Table 3). This technique involves RNA-guided engineered nucleases because of its simplicity, efficiency and versatility. In tomato, the CRISPR/Cas9 approach has been used to make modifications in the ARGONAUTE7 (SlAGO7) gene. The mutation created in the SlAGO7 was found to be stable in 
the subsequent generations of genome-edited tomato lines. The SlAGO7 gene is responsible for the post-transcription degradation of AUXIN RESPONSE FACTOR (ARF) genes. Loss-of-function of this gene causes the conversion of compound leaves into needle-like or wiry leaves, hence silencing of this gene resulted in reduced levels of ARF and altered leaf phenotype in first and second generations successfully [7]. Furthermore, anthocyanins are a class of secondary metabolites which play a critical role in providing protection against biotic and abiotic stresses in plants [39,40].

Most of the genes involved in anthocyanin synthesis in plants have been identified. In addition to these genes, three families of transcription factors (TF) have been identified to play a role in the anthocyanin synthesis [40]. Under both ultraviolet (UV) and visible light, bZIP transcription factor, HY5 has been reported to have major effect in accumulation of anthocyanin. In order to identify TF in HY5 dependent and independent manner, a tomato cultivar 'Indigo Rose' bearing high anthocyanin containing purple tomatoes was selected and CRISPR/Cas9 was used to generate the mutants. Interestingly, transcriptome analysis of various tissues of hy5 mutant lines revealed that eight TFs were found to be controlling anthocyanin biosynthesis independently [40]. Similarly, the CRISPR/Cas9 technique has been explored to develop high-quality and stress-resistant tomato lines [7,41-44].

Table 3. Details of genome-editing efforts performed to make site specific mutations in important genes in tomato.

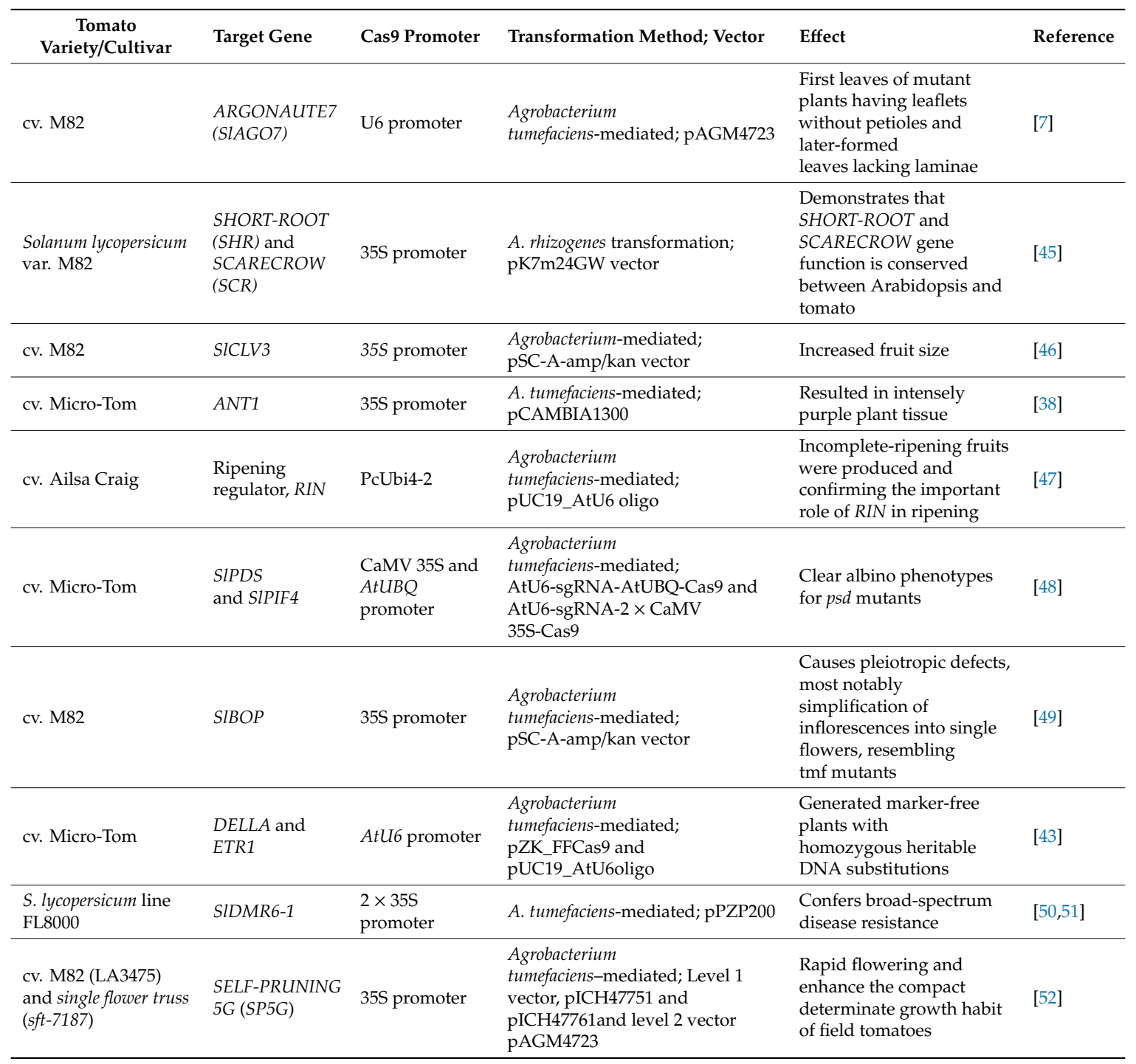


Table 3. Cont.

\begin{tabular}{|c|c|c|c|c|c|}
\hline $\begin{array}{c}\text { Tomato } \\
\text { Variety/Cultivar }\end{array}$ & Target Gene & Cas9 Promoter & Transformation Method; Vector & Effect & Reference \\
\hline $\begin{array}{l}\text { GCR758, a derivative } \\
\text { of tomato cultivar } \\
\text { Moneymaker }\end{array}$ & slmlo1 & U6 promoter & $\begin{array}{l}\text { A. tumefaciens-mediated; } \\
\text { pAGM } 4723\end{array}$ & $\begin{array}{l}\text { Developed transgene-free } \\
\text { powdery mildew resistant } \\
\text { tomato variety, 'Tomelo' }\end{array}$ & [53] \\
\hline cv. Ailsa Craig & SlMAPK3 & $\begin{array}{l}\text { Ubi-H } \\
\text { promoter }\end{array}$ & $\begin{array}{l}\text { Agrobacterium -mediated } \\
\text { cotyledon transformation; } \\
\text { pYLCRISPR/Cas9 vector }\end{array}$ & $\begin{array}{l}\text { Suggests that SIMAPK3 is } \\
\text { involved in drought } \\
\text { response in tomato plants }\end{array}$ & {$[54]$} \\
\hline cv. Micro-Tom & $\begin{array}{l}\text { SlGAD2 and } \\
\text { SlGAD3 }\end{array}$ & AtU6 promoter & $\begin{array}{l}\text { Agrobacterium } \\
\text { tumefaciens-mediated; } \\
\text { pZD_AtU6_Hpger_Cas9_ } \\
\text { NPTII and pDeCas9_Kan }\end{array}$ & $\begin{array}{l}\text { Increased GABA } \\
\text { accumulation by } 7 \text { to } \\
15 \text { fold }\end{array}$ & [56] \\
\hline $\begin{array}{l}\text { cv. Micro-Tom and } \\
\text { Ailsa Craig }\end{array}$ & SIIAA9 & $\begin{array}{l}2 \times C a M V 35 S \\
\text { promoter }\end{array}$ & $\begin{array}{l}\text { Agrobacterium } \\
\text { tumefaciens-mediated; } \\
\text { pEgP526-2A-GFBSD2 }\end{array}$ & $\begin{array}{l}\text { Morphological changes in } \\
\text { leaf shape and } \\
\text { seedless fruit }\end{array}$ & [51] \\
\hline $\begin{array}{l}\text { cv. Ailsa Craig (AC) } \\
\text { and cv. } \\
\text { Micro-Tom (MT) }\end{array}$ & $\begin{array}{l}\text { Phytoene } \\
\text { desaturase }\end{array}$ & Ubi promoter & $\begin{array}{l}\text { Agrobacterium-mediated; } \\
\text { pYLCRISPR/Cas9-slyPDS and } \\
\text {-GABA vector }\end{array}$ & $\begin{array}{l}\text { GABA accumulation } \\
\text { enhance in both leaves } \\
\text { and fruits }\end{array}$ & [58] \\
\hline
\end{tabular}

\section{Mutation Mapping Approaches}

\subsection{MutMap Approach}

MutMap is a recently developed efficient and affordable forward genetic approach which is based on the high-throughput next-generation sequencing technique. MutMap has been demonstrated in rice for the first time to map mutations causing color change of leaves and semi-dwarf plant structure [59]. The major steps involved in the MutMap approach is illustrated in Figure 1. In a study conducted by [59], a rice cultivar was chemically mutagenized to develop a mutant population. The mutant lines mostly carry recessive mutations and such mutations do not impact phenotypic alteration. Therefore, the mutant lines need to be self-pollinated to obtain homozygous mutant populations in subsequent generations. Then the mutants with recessive mutation need to be identified based on the phenotypic screening and crossed with the wild type of the same cultivar. The obtained F1 hybrid plants need to self-crossed to obtain F2 generation. Furthermore, the bulk DNA of F2 population can be sequenced and mapped with reference genome of wild-type cultivar to identify the SNPs and insertions-deletions putatively related to the phenotype [59]. Due to the high applicability and reduced sequencing cost, MutMap can be utilized to identify desired genes with agronomic importance in lesser time [59]. The MutMap technique has recently been used in tomato to map mutations induced in the Micro-Tom cultivars [60]. A segregating F2 population have been developed by crossing the homozygous mutant line with a wild Micro-Tom, and separate pools of plants showing mutant and wildtype phenotypes have been sequenced with the NGS method to map the causal mutation. This study has demonstrated that the mapping of causal mutation can be performed within ten to twelve months in tomato with affordable cost. 


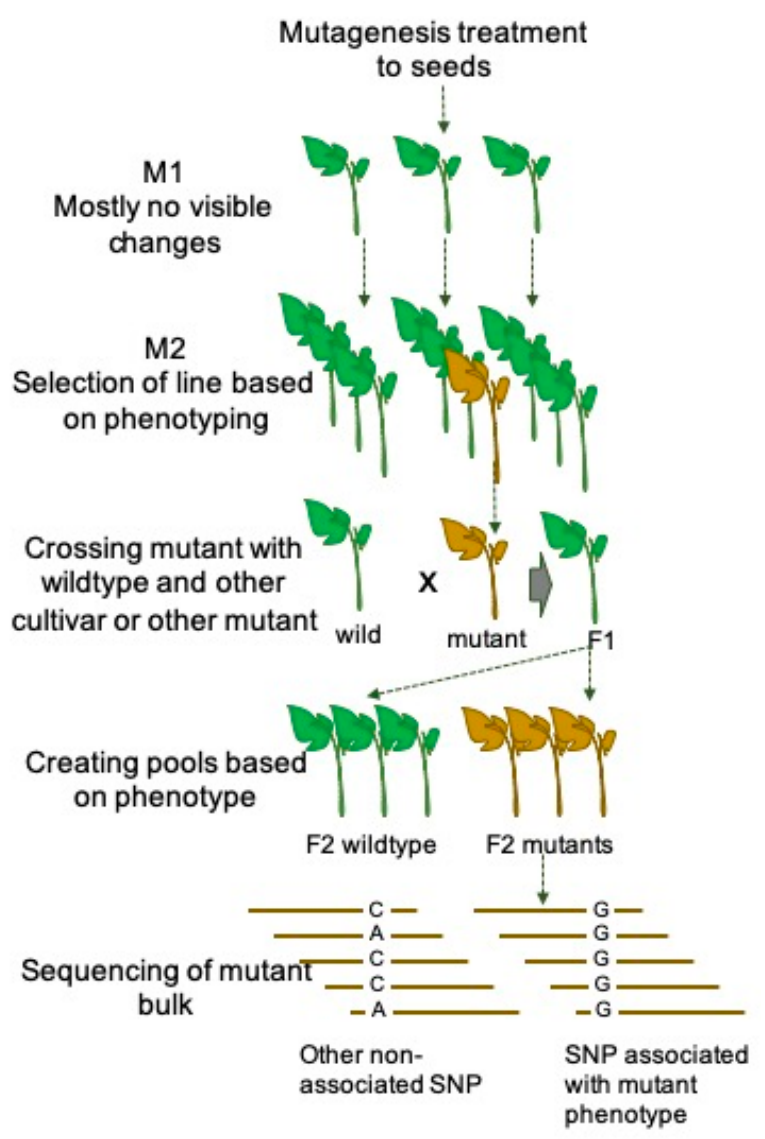

Figure 1. Schematic representation of atypical mutmap strategy exploring next generation sequencing to identify the causal mutations resulted into altered phenotype in plants. The mutmap strategy wasfirst demonstrated by Abe et al. (2012).

\subsection{MutChromSeq Approach}

Finding a randomly induced mutation in a whole genome is like finding a needle in a haystack. However, with the advent of DNA sequencing, identifying genome-wide sequence variations has become easier. On the contrary, identification of sequence variation with high confidence using genome sequencing approach is easier only for plants with small genomes like Arabidopsis and rice while it is an expensive and computationally challenging approach for plants with larger genomes like barley and wheat. A recently discovered technique for rapid detection of casual mutation called MutChromSeq (Mutant Chromosome Sequencing) has been applied to identify novel genes in plants [61]. In this technique, classical mutagenesis is combined with chromosome flow sorting to filter out the desired region where we can find the desired gene. In this approach, the chromosomes are filtered out where particular gene is located on the basis of fluorescent marker tags (Figure 2). This is followed by sequencing of chromosomes of both mutant and non-mutants to find the desired gene of interest. This technique of isolating gene and DNA sequences can be applied to plants with complex and polyploidy genomes as well as genomes with large chromosome which are devoid of recombination and hence, reducing the need for recombination-based genetic mapping. This technique has been successfully employed in the case of barley and wheat for cloning of Eceriferum- $q$ and Pm2 gene [61]. This technique is applied to plants which are responsive for mutagenesis, the desired mutation results in significantly visible phenotypic change and prior information of the chromosome where the gene is located is available. Hence, it can be an inexpensive and robust technique of cloning of known unmanageable genes [61]. There is not a single report on MutChromSeq analysis in tomato, but its diploid nature and the availability of whole genome sequence make it easier to implement this technique for isolating and cloning desired genes in future. 


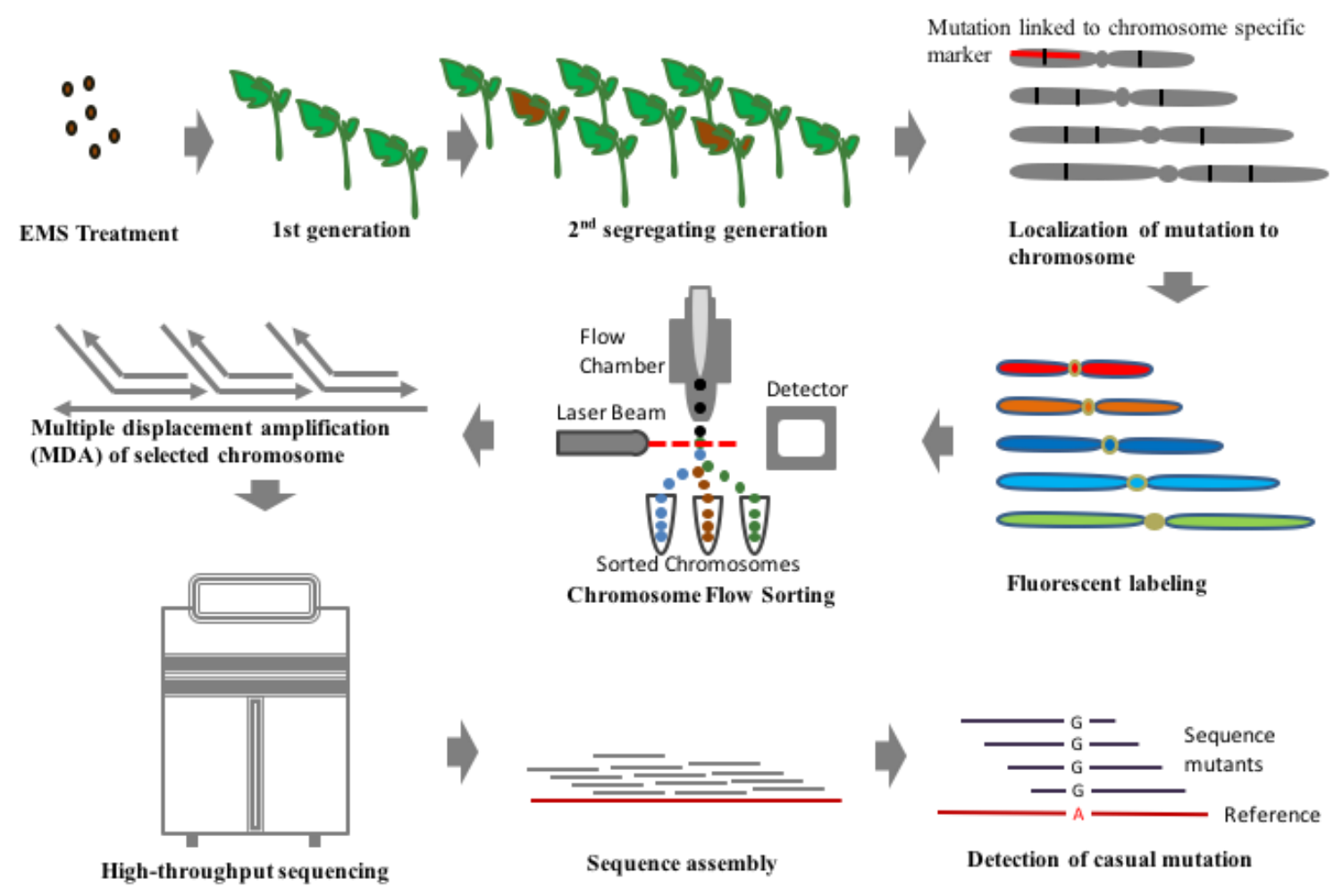

Figure 2. Generalised flowchart showing steps involved in the MutChromSeq approach which can be conveniently used for the mapping of casual mutation in plant species with larger genome size. To select chromosome for the sequencing, first mapping of confirmed mutant need to be done with markers known to be linked with each chromosome. Subsequently, chromosomes labelled with fluorescence dye can be sorted with flowcytometric techniques and sequenced selectively with high throughput techniques. Later analysis of sequencing data from the mutant line can be used to locate the casual mutation precisely similarly as described in Figure 1.

\subsection{Whole-Genome Sequencing (WGS)-Based Mapping}

Once a high-quality reference genome available for any species, re-sequencing of many genotypes for the species become much easier, quicker and cheap. With the availability of whole genome sequence of S. lycopersicum, various attempts have been made for its re-sequencing using NGS to identify sequence variation among different cultivars [62]. Shirasawa et al. (2013) conducted re-sequencing of Micro-Tom mutants generated through EMS and gamma-ray radiation mutagenesis to locate the induced SNP and In Del mutations. To identify these mutations, paired-end reads by Illumina sequencing have been obtained for 8 Micro-Tom lines and mapped to the tomato reference genome. The study has successfully identified about a million SNPs and InDels [62]. Such whole genome re-sequencing approach generates a valuable resource of mutations to perform reverse genetic studies. The catalogue of identified mutation can be screened to sort out candidate variation possibly impacting gene function. For instance, SNPs causing non-synonymous changes can be detected using the genome annotation information. Considering the continuously reducing sequencing cost, projects aiming for the sequencing of the entire mutant population are anticipated in several crop species including tomato (Table 4). 
Table 4. List of significant efforts made towards mapping of causal mutation in tomato.

\begin{tabular}{|c|c|c|c|c|}
\hline Tomato Cultivar & Mutant Trait & Mapping Method & Mutation (Position) & Reference \\
\hline Moneymaker & $\begin{array}{l}\text { gib-2 } \\
\text { gib-1 } \\
\text { gib-3 }\end{array}$ & Linkage mapping & $\begin{array}{l}\text { Chr } 1 \\
\text { Chr } 6 \\
\text { Chr } 7\end{array}$ & [63] \\
\hline VF 11 and K93 & $R g-1$ & $\begin{array}{l}\text { Classical and RFLP } \\
\text { (restriction } \\
\text { fragment length } \\
\text { polymorphism) } \\
\text { mapping }\end{array}$ & Chr 3 (51 cM) & [64] \\
\hline $\begin{array}{l}\text { phytochrome A (phy } \\
\text { A)-deficient fri mutants }\end{array}$ & fri & Classical map & Chr 10 (29 cM) & [65] \\
\hline $\begin{array}{l}\text { phyB1-deficient tri } \\
\text { mutants }\end{array}$ & tri, hp-2 & $\begin{array}{c}\text { Classical and RFLP } \\
\text { mapping }\end{array}$ & Chr 1 (33 cM) & [65] \\
\hline Ailsa Craig and Liberto & $\begin{array}{l}\text { Cnr (colorless } \\
\text { nonripening) }\end{array}$ & $\begin{array}{l}\text { RFLP and Linkage } \\
\text { Analysis }\end{array}$ & Chr 2 (4.1-9.2 cM) & [66] \\
\hline LA3179 and LA348 & Beta $(B)$ and old-gold $(o g)$ & Map-based cloning & Chr 6 & [67] \\
\hline $\begin{array}{l}\text { LA2453, LA2455, and } \\
\text { LA483 }\end{array}$ & $\begin{array}{l}\text { Green-ripe (Gr) and } \\
\text { Never-ripe } 2(\mathrm{Nr}-2)\end{array}$ & Positional cloning & Chr 1 (2 cM) & [68] \\
\hline Liberto and Ailsa Craig & $\begin{array}{l}\text { Colorless non-ripening } \\
\qquad(\mathrm{Cnr})\end{array}$ & Positional cloning & Chr $2(13 \mathrm{~kb})$ & [69] \\
\hline $\begin{array}{c}\text { LA3534, LA4074 and } \\
\text { LA4076 }\end{array}$ & green-flesh $(g f)$ & Positional cloning & Chr 8 (45 cM) & [70] \\
\hline Castlemart & Od-2 & Genetic mapping & Chr 11 (16 cM) & [71] \\
\hline $\begin{array}{l}\text { Solanum lycopersicum } \\
\text { S. lycopersicum (pe/pe) }\end{array}$ & lutescent 2 (l2) & Linkage mapping & Chr 10L (7.5 cM) & [72] \\
\hline $\begin{array}{l}\text { (LA2467) and } \\
\text { S. pimpinellifolium (PE/PE) } \\
\text { (LA1589) }\end{array}$ & pe & Genetic mapping & Chr 1 (424 kb) & [73] \\
\hline $\begin{array}{l}\text { P15C12 Micro-Tom glossy } \\
\text { mutant } \times \text { dwarf mutant } \\
\text { from the M82 cultivar }\end{array}$ & P15C12 & Genetic mapping & Chr 11 (4.84 Mb) & [74] \\
\hline Micro-Tom & pyp1 & $\begin{array}{l}\text { Candidate gene } \\
\text { approach with } \\
\text { map-based cloning }\end{array}$ & Chr 1 (3.4 cM) & [75] \\
\hline $\begin{array}{l}\text { af }(\text { LA1049) } \times \text { IL5-2 } \\
(\text { LA4055) }\end{array}$ & Af & $\begin{array}{l}\text { Map-Based } \\
\text { Cloning }\end{array}$ & Chr 5 & [76] \\
\hline M82 & $N x d 1$ & Map-based cloning & Chr 12 (40-42 Mbp) & [77] \\
\hline
\end{tabular}

\section{Tomato Mutant Resources}

\subsection{Genes that Make Tomatoes (http://zamir.sgn.cornell.edu/mutants/)}

A resource of well characterized homozygous tomato mutants with the genetic background of cultivar M82 has been developed using EMS and fast-neutron mutagenesis approaches. To identify mutants for the agronomically important trait, extensive screening of around 13,000 M2 populations have been performed. Based on the phenotypic characterization, the mutant population was catalogued into 15 categories and 48 sub-categories. About 3417 mutations have been confirmed and characterized for the phenotype. Most of the mutations in the database are pleiotropic. The phenotypic data and images of the mutants are also made available on the database website. The mutant seeds can be obtained after requesting email with desired list of mutant codes.

\subsection{LycoTILL (http://wwww.agrobios.it/tilling/)}

LycoTILL is a database for tomato mutant lines generated through the EMS mutagenesis in genetic background of cv. Red Setter. The phenotypic data and images of confirmed mutants are available on-line in this database. The tomato cv. Red Setter was used because it is a highly productive processing variety and it has a vegetative cycle of about 110 days. The M2 mutant population has been phenotypically screened at different developmental stages and the recorded data then catalogued into 17 classes and 52 sub-classes. The database can be searched by phenotype, plant code and family name. 
About 6677 M2 and 5872 M3 families are comprised in this mutant collection and seeds of both the populations are made available.

\section{The Red Setter TILLING Platform}

The processing tomato cv. Red Setter was treated with EMS ( $0.7 \%$ and $1 \%)$ to apply TILLING to tomato. The DNA from $5221 \mathrm{M} 3$ families was prepared to set TILLING platform and the M3 families were selected on the basis of seed abundance. About 66 induced point mutations were identified. Among these, SNPs were identified in both coding and non-coding genome. Among the coding region, both sense and missense mutations were found and missense mutations were predicated by the SIFT programme (Sorting Intolerant From Tolerant) to be deleterious for the activity of protein. This genetic resource could be used to discover high-throughput mutations (Minoia 2010).

\section{TOMATOMA (http://tomatoma.nbrp.jp/indexAction.do)}

TOMATOMA is a database for tomato mutant lines in genetic background of Micro-Tom cultivar. The Micro-Tom is worldwide used as a model tomato cultivar in molecular biology research due to characteristic features like small plant size $(10-20 \mathrm{~cm}$ height), short life cycle (fruit maturity in 70-90 days after sowing), ideal for indoor cultivation, can perform both interspecific and intraspecific cross proliferation, ease of proliferation, and highly efficient genetic transformation [78-80]. Therefore, to accelerate functional genomics studies, the mutant population of Micro-Tom has great importance. The mutant population have been developed using EMS and gamma radiations [80]. About 90,000 plants from M2 families were catalogued into 15 categories and 48 subcategories after confirming the mutant phenotypes and provided in a freely accessible database, TOMATOMA [80]. The aim of creating the TOMATOMA database was to provide the mutant seeds of Micro-Tom to the scientific community. These are available for a small fee on completion of a MTA (material transfer agreement). The images contained in the database are divided according to the phenotype and growth stage. The phenotype list includes images of seeds, plant size and habit, leaf morphology and color, flowering timing, inflorescence structure, flower morphology, color and size, fruit morphology, color and ripening, sterility and disease and stress response. The growth stage list includes images of germination, leaf production, side shoot, inflorescence, flowering fruit and ripening. The mutant resource provides, EMS mutagenesis lines, gamma irradiation-induced mutant lines, EMS and gamma irradiation-induced mutant lines, T-DNA tag lines and wild-type cultivars. All the three mutant resources described here need to be explored efficiently to accelerate the tomato improvement program (Table 5).

Table 5. Details of three major online resources, Genes that make tomatoes, LycoTILL, and TOMATOMA providing characterised mutant lines in tomato.

\begin{tabular}{|c|c|c|c|}
\hline Information Resource & Genes that Make Tomatoes & LycoTILL & TOMАТОМА \\
\hline Genetic background & Inbred variety M82 & cv. Red Setter & Micro-Tom \\
\hline Mutagens & EMS and fast-neutrons & EMS & EMA and gamma-rays \\
\hline Mutagen dosage & $\begin{array}{l}0.5 \% \text { EMS and } 12 \mathrm{~Gy}, 15 \mathrm{~Gy} \\
\text { Fast-neutron irradiation }\end{array}$ & $0.7 \%$ and $1 \%$ EMS & $0.3,0.5,1$ and $1.5 \%$ EMS \\
\hline $\begin{array}{l}\text { Total M2/M3 families } \\
\text { included }\end{array}$ & $\begin{array}{l}6000 \text { EMS and } 7000 \text { fast neutron } \\
\text { M2 families }\end{array}$ & $\begin{array}{l}6677 \mathrm{M} 2 \text { and } 5872 \mathrm{M} 3 \\
\text { families }\end{array}$ & $\begin{array}{l}4371 \text { EMS and } 6422 \\
\text { gamma-ray irradiated } \\
\text { families }\end{array}$ \\
\hline Total mutants catalogued & 3417 & - & 1048 \\
\hline Total categories & $\begin{array}{l}15 \text { primary and } 48 \text { secondary } \\
\text { categories }\end{array}$ & $\begin{array}{l}17 \text { classes and } 52 \\
\text { sub-classes }\end{array}$ & $\begin{array}{l}15 \text { major and } 48 \\
\text { sub-categories }\end{array}$ \\
\hline Managed by & Solanaceae resource & Metapontum Agrobios & $\begin{array}{c}\text { National Bioresource Project } \\
\text { Tomato (NBRP) }\end{array}$ \\
\hline Seed request & $\begin{array}{l}\text { Seeds obtained by sending email } \\
\text { for the list of mutant codes }\end{array}$ & $\begin{array}{l}\text { By signing of a Material } \\
\text { Transfer Agreement } \\
\text { (MTA) document }\end{array}$ & By sending 2 copies of MTA \\
\hline
\end{tabular}




\section{Limitations and Challenges for Mutagenesis in Tomato}

Tomato has distinct characteristics such as the phylogenetic distance from other model plants as well not having any significant similarity in sequence information with other plant species. Therefore, even the availability of many efficient tools for both forward and reverse genetics is restricted in tomato. Even though around 30,000-40,000 genes have been identified and hundreds of tomato mutants are available, only a few links have been found for DNA sequences and mutants so far. Furthermore, high-throughput mutagenesis in tomato is challenging due to its short shelf life, long life cycle, time-consuming transformation and large-scale processing for seeds' extraction immediately after the harvest from its jelly. Another big limitation is with transformation methods such as dipping and infiltration, which have been reported to be inefficient in tomato plants. With regards to efficient insertional mutagenesis in tomato, there are still no inhabitant transposons characterized in tomato. The development of gene editing and mapping approaches have enabled the progressions in the improvement of tomato, however, the above-mentioned limitations still require the implication of a combination of approaches and advancements towards tomato mutagenesis research.

Author Contributions: J.C., A.A., H.S., and R.D. conceived the idea J.C. and A.A. equally contributed to this work and prepared the first draft of the manuscript. V.B., S.C., N.K., Z.M., A.K., S.K.Y., and S.M.S. reviewed the manuscript with valuable inputs. R.D. and H.S. edited and finalized the manuscript. All authors read and approved the final manuscript.

Funding: This research was funded by Department of Biotechnology, Government of India.

Acknowledgments: Authors are thankful to the Department of Biotechnology, Gov. of India for the Ramalingaswami Fellowship award to R.D. and H.S.

Conflicts of Interest: The authors declare no conflict of interest.

\section{References}

1. Just, D.; Garcia, V.; Fernandez, L.; Bres, C.; Mauxion, J.-P.; Petit, J.; Jorly, J.; Assali, J.; Bournonville, C.; Ferrand, C. Micro-Tom mutants for functional analysis of target genes and discovery of new alleles in tomato. Plant Biotechnol. 2013, 30, 225-231. [CrossRef]

2. Ranjan, A.; Ichihashi, Y.; Sinha, N.R. The tomato genome: Implications for plant breeding, genomics and evolution. Genome Biol. 2012, 13, 167. [CrossRef]

3. Consortium, T.G. The tomato genome sequence provides insights into fleshy fruit evolution. Nature 2012, 485, 635. [CrossRef]

4. Yao, L.; Zhang, Y.; Liu, C.; Liu, Y.; Wang, Y.; Liang, D.; Liu, J.; Sahoo, G.; Kelliher, T. OsMATL mutation induces haploid seed formation in indica rice. Nat. Plants 2018, 4, 530. [CrossRef] [PubMed]

5. Tripathi, J.N.; Ntui, V.O.; Ron, M.; Muiruri, S.K.; Britt, A.; Tripathi, L. CRISPR/Cas9 editing of endogenous banana streak virus in the B genome of Musa spp. overcomes a major challenge in banana breeding. Commun. Biol. 2019, 2, 46. [CrossRef] [PubMed]

6. Tian, S.; Jiang, L.; Cui, X.; Zhang, J.; Guo, S.; Li, M.; Zhang, H.; Ren, Y.; Gong, G.; Zong, M. Engineering herbicide-resistant watermelon variety through CRISPR/Cas9-mediated base-editing. Plant Cell Rep. 2018, 37, 1353-1356. [CrossRef]

7. Brooks, C.; Nekrasov, V.; Lippman, Z.B.; Van Eck, J. Efficient gene editing in tomato in the first generation using the clustered regularly interspaced short palindromic repeats/CRISPR-associated9 system. Plant Physiol. 2014, 166, 1292-1297. [CrossRef]

8. Lor, V.S.; Starker, C.G.; Voytas, D.F.; Weiss, D.; Olszewski, N.E. Targeted mutagenesis of the tomato PROCERA gene using transcription activator-like effector nucleases. Plant Physiol. 2014, 166, 1288-1291. [CrossRef]

9. Wisman, E.; Koornneef, M.; Chase, T.; Lifshytz, E.; Ramanna, M.; Zabel, P. Genetic and molecular characterization of an Adh-1 null mutant in tomato. Mol. Gen. Genet. 1991, 226, 120-128. [PubMed]

10. Menda, N.; Semel, Y.; Peled, D.; Eshed, Y.; Zamir, D. In silico screening of a saturated mutation library of tomato. Plant J. 2004, 38, 861-872. [CrossRef]

11. Adamu, A.; Aliyu, H. Morphogical effects of sodium azide on tomato (Lycopersicon esculentum Mill). Sci. World J. 2007, 2, 9-12. [CrossRef] 
12. Kostov, K.; Batchvarova, R.; Slavov, S. Application of chemical mutagenesis to increase the resistance of tomato to Orobanche ramosa L. Bulg. J. Agric. Sci. 2007, 13, 505-513.

13. Matsukura, C.; Yamaguchi, I.; Inamura, M.; Ban, Y.; Kobayashi, Y.; Yin, Y.-g.; Saito, T.; Kuwata, C.; Imanishi, S.; Nishimura, S. Generation of gamma irradiation-induced mutant lines of the miniature tomato (Solanum lycopersicum L.) cultivar 'Micro-Tom'. Plant Biotechnol. 2007, 24, 39-44. [CrossRef]

14. Minoia, S.; Petrozza, A.; D’Onofrio, O.; Piron, F.; Mosca, G.; Sozio, G.; Cellini, F.; Bendahmane, A.; Carriero, F. A new mutant genetic resource for tomato crop improvement by TILLING technology. BMC Res. Notes 2010, 3, 69. [CrossRef]

15. Piron, F.; Nicolaï, M.; Minoïa, S.; Piednoir, E.; Moretti, A.; Salgues, A.; Zamir, D.; Caranta, C.; Bendahmane, A. An induced mutation in tomato eIF4E leads to immunity to two potyviruses. PLoS ONE 2010, 5, e11313. [CrossRef]

16. Watanabe, S.; Mizoguchi, T.; Aoki, K.; Kubo, Y.; Mori, H.; Imanishi, S.; Yamazaki, Y.; Shibata, D.; Ezura, H. Ethylmethanesulfonate (EMS) mutagenesis of Solanum lycopersicum cv. Micro-Tom for large-scale mutant screens. Plant Biotechnol. 2007, 24, 33-38. [CrossRef]

17. Hammond-Kosack, K.E.; Jones, D.A.; Jones, J.D. Identification of two genes required in tomato for full Cf-9-dependent resistance to Cladosporium fulvum. Plant Cell 1994, 6, 361-374.

18. Kurowska, M.; Daszkowska-Golec, A.; Gruszka, D.; Marzec, M.; Szurman, M.; Szarejko, I.; Maluszynski, M. TILLING-a shortcut in functional genomics. J. Appl. Genet. 2011, 52, 371. [CrossRef]

19. Martí, E.; Gisbert, C.; Bishop, G.J.; Dixon, M.S.; García-Martínez, J.L. Genetic and physiological characterization of tomato cv. Micro-Tom. J. Exp. Bot. 2006, 57, 2037-2047. [CrossRef]

20. Gilchrist, E.; Haughn, G. Reverse genetics techniques: Engineering loss and gain of gene function in plants. Brief. Funct. Genom. 2010, 9, 103-110. [CrossRef]

21. Li, X.; Song, Y.; Century, K.; Straight, S.; Ronald, P.; Dong, X.; Lassner, M.; Zhang, Y. A fast neutron deletion mutagenesis-based reverse genetics system for plants. Plant J. 2001, 27, 235-242. [CrossRef]

22. Lee, H.-K.; Mysore, K.S.; Wen, J. Tnt1 Insertional Mutagenesis in Medicago truncatula. Functional Genomics in Medicago truncatula; Humana Press: New York, NY, USA, 2018; pp. 107-114.

23. Sun, S.; Chen, Y.; Cheng, J.; Li, Q.; Zhang, Z.; Lan, Z. Isolation, characterization, genomic sequencing, and GFP-marked insertional mutagenesis of a high-performance nitrogen-fixing bacterium, Kosakonia radicincitans GXGL-4A and visualization of bacterial colonization on cucumber roots. Folia Microbiol. 2018, 1-14. [CrossRef]

24. Cooley, M.B.; Yoder, J.; Goldsbrough, A.; Still, D. Site-selected insertional mutagenesis of tomato with maizeAc andDs elements. Mol. Gen. Genet. 1996, 252, 184-194. [CrossRef]

25. Cooley, M.B.; Yoder, J.I. Insertional inactivation of the tomato polygalacturonase gene. Plant Mol. Biol. 1998, 38, 521-530. [CrossRef]

26. Healy, J.; Corr, C.; DeYoung, J.; Baker, B. Linked and unlinked transposition of a genetically marked Dissociation element in transgenic tomato. Genetics 1993, 134, 571-584.

27. Goldsbrough, A.P.; Tong, Y.; Yoder, J.I. Lc as a non-destructive visual reporter and transposition excision marker gone for tomato. Plant J. 1996, 9, 927-933. [CrossRef]

28. Mathews, H.; Clendennen, S.K.; Caldwell, C.G.; Liu, X.L.; Connors, K.; Matheis, N.; Schuster, D.K.; Menasco, D.; Wagoner, W.; Lightner, J. Activation tagging in tomato identifies a transcriptional regulator of anthocyanin biosynthesis, modification, and transport. Plant Cell 2003, 15, 1689-1703. [CrossRef] [PubMed]

29. Roldan, M.V.G.; Périlleux, C.; Morin, H.; Huerga-Fernandez, S.; Latrasse, D.; Benhamed, M.; Bendahmane, A. Natural and induced loss of function mutations in SIMBP21 MADS-box gene led to jointless-2 phenotype in tomato. Sci. Rep. 2017, 7, 4402. [CrossRef]

30. Zhang, J.; Chen, R.; Xiao, J.; Qian, C.; Wang, T.; Li, H.; Ouyang, B.; Ye, Z. A single-base deletion mutation in SIIAA9 gene causes tomato (Solanum lycopersicum) entire mutant. J. Plant Res. 2007, 120, 671-678. [CrossRef]

31. Uluisik, S.; Chapman, N.H.; Smith, R.; Poole, M.; Adams, G.; Gillis, R.B.; Besong, T.M.; Sheldon, J.; Stiegelmeyer, S.; Perez, L. Genetic improvement of tomato by targeted control of fruit softening. Nat. Biotechnol. 2016, 34, 950. [CrossRef]

32. Yang, L.; Huang, W.; Xiong, F.; Xian, Z.; Su, D.; Ren, M.; Li, Z. Silencing of S1 PL, which encodes a pectate lyase in tomato, confers enhanced fruit firmness, prolonged shelf-life and reduced susceptibility to grey mould. Plant Biotechnol. J. 2017, 15, 1544-1555. [CrossRef] [PubMed]

33. Rothan, C.; Diouf, I.; Causse, M. Trait discovery and editing in tomato. Plant J. 2019, 97, 73-90. [CrossRef] 
34. Mao, Y.; Botella, J.R.; Liu, Y.; Zhu, J.-K. Gene Editing in Plants-Progress and Challenges. Natl. Sci. Rev. 2019. [CrossRef]

35. Jung, C.; Capistrano-Gossmann, G.; Braatz, J.; Sashidhar, N.; Melzer, S. Recent developments in genome editing and applications in plant breeding. Plant Breed. 2018, 137, 1-9. [CrossRef]

36. Mani, M.; Kandavelou, K.; Dy, F.J.; Durai, S.; Chandrasegaran, S. Design, engineering, and characterization of zinc finger nucleases. Biochem. Biophys. Res. Commun. 2005, 335, 447-457. [CrossRef]

37. Hilioti, Z.; Ganopoulos, I.; Ajith, S.; Bossis, I.; Tsaftaris, A. A novel arrangement of zinc finger nuclease system for in vivo targeted genome engineering: The tomato LEC1-LIKE4 gene case. Plant Cell Rep. 2016, 35, 2241-2255. [CrossRef] [PubMed]

38. Čermák, T.; Baltes, N.J.; Čegan, R.; Zhang, Y.; Voytas, D.F. High-frequency, precise modification of the tomato genome. Genome Biol. 2015, 16, 232. [CrossRef] [PubMed]

39. Gould, K.S. Nature's Swiss army knife: The diverse protective roles of anthocyanins in leaves. BioMed Res. Int. 2004, 2004, 314-320. [CrossRef]

40. Qiu, Z.; Wang, H.; Li, D.; Yu, B.; Hui, Q.; Yan, S.; Huang, Z.; Cui, X.; Cao, B. Identification of Candidate HY5-dependent and-independent Regulators of Anthocyanin Biosynthesis in Tomato. Plant Cell Physiol. 2018. [CrossRef]

41. Jacobs, T.B.; Zhang, N.; Patel, D.; Martin, G.B. Generation of a collection of mutant tomato lines using pooled CRISPR libraries. Plant Physiol. 2017, 174, 2023-2037. [CrossRef]

42. Shimatani, Z.; Ariizumi, T.; Fujikura, U.; Kondo, A.; Ezura, H.; Nishida, K. Targeted Base Editing with CRISPR-Deaminase in Tomato. In Plant Genome Editing with CRISPR Systems; Humana Press: New York, NY, USA, 2019; pp. 297-307.

43. Shimatani, Z.; Kashojiya, S.; Takayama, M.; Terada, R.; Arazoe, T.; Ishii, H.; Teramura, H.; Yamamoto, T.; Komatsu, H.; Miura, K. Targeted base editing in rice and tomato using a CRISPR-Cas9 cytidine deaminase fusion. Nat. Biotechnol. 2017, 35, 441. [CrossRef]

44. Zsögön, A.; Čermák, T.; Naves, E.R.; Notini, M.M.; Edel, K.H.; Weinl, S.; Freschi, L.; Voytas, D.F.; Kudla, J.; Peres, L.E.P. De novo domestication of wild tomato using genome editing. Nat. Biotechnol. 2018. [CrossRef]

45. Rivero, R.M.; Mestre, T.C.; Mittler, R.; Rubio, F.; GARCIA-SANCHEZ, F.; Martinez, V. The combined effect of salinity and heat reveals a specific physiological, biochemical and molecular response in tomato plants. Plant Cell Environ. 2014, 37, 1059-1073. [CrossRef]

46. Xu, C.; Liberatore, K.L.; MacAlister, C.A.; Huang, Z.; Chu, Y.-H.; Jiang, K.; Brooks, C.; Ogawa-Ohnishi, M.; Xiong, G.; Pauly, M. A cascade of arabinosyltransferases controls shoot meristem size in tomato. Nat. Genet. 2015, 47, 784. [CrossRef]

47. Ito, Y.; Nishizawa-Yokoi, A.; Endo, M.; Mikami, M.; Toki, S. CRISPR/Cas9-mediated mutagenesis of the RIN locus that regulates tomato fruit ripening. Biochem. Biophys. Res. Commun. 2015, 467, 76-82. [CrossRef]

48. Pan, C.; Ye, L.; Qin, L.; Liu, X.; He, Y.; Wang, J.; Chen, L.; Lu, G. CRISPR/Cas9-mediated efficient and heritable targeted mutagenesis in tomato plants in the first and later generations. Sci. Rep. 2016, 6, 24765. [CrossRef] [PubMed]

49. Xu, C.; Park, S.J.; Van Eck, J.; Lippman, Z.B. Control of inflorescence architecture in tomato by BTB/POZ transcriptional regulators. Genes Dev. 2016, 30, 2048-2061. [CrossRef]

50. de Toledo Thomazella, D.P.; Brail, Q.; Dahlbeck, D.; Staskawicz, B.J. CRISPR-Cas9 mediated mutagenesis of a DMR6 ortholog in tomato confers broad-spectrum disease resistance. bioRxiv 2016, 064824.

51. Ueta, R.; Abe, C.; Watanabe, T.; Sugano, S.S.; Ishihara, R.; Ezura, H.; Osakabe, Y.; Osakabe, K. Rapid breeding of parthenocarpic tomato plants using CRISPR/Cas9. Sci. Rep. 2017, 7, 507. [CrossRef] [PubMed]

52. Soyk, S.; Müller, N.A.; Park, S.J.; Schmalenbach, I.; Jiang, K.; Hayama, R.; Zhang, L.; Van Eck, J.; Jiménez-Gómez, J.M.; Lippman, Z.B. Variation in the flowering gene SELF PRUNING 5G promotes day-neutrality and early yield in tomato. Nat. Genet. 2017, 49, 162. [CrossRef]

53. Nekrasov, V.; Wang, C.; Win, J.; Lanz, C.; Weigel, D.; Kamoun, S. Rapid generation of a transgene-free powdery mildew resistant tomato by genome deletion. Sci. Rep. 2017, 7, 482. [CrossRef]

54. Wang, L.; Chen, L.; Li, R.; Zhao, R.; Yang, M.; Sheng, J.; Shen, L. Reduced drought tolerance by CRISPR/Cas9-mediated SIMAPK3 mutagenesis in tomato plants. J. Agric. Food Chem. 2017, 65, 8674-8682. [CrossRef] 
55. Klap, C.; Yeshayahou, E.; Bolger, A.M.; Arazi, T.; Gupta, S.K.; Shabtai, S.; Usadel, B.; Salts, Y.; Barg, R. Tomato facultative parthenocarpy results from Sl AGAMOUS-LIKE 6 loss of function. Plant Biotechnol. J. 2017, 15, 634-647. [CrossRef]

56. Nonaka, S.; Arai, C.; Takayama, M.; Matsukura, C.; Ezura, H. Efficient increase of r-aminobutyric acid (GABA) content in tomato fruits by targeted mutagenesis. Sci. Rep. 2017, 7, 7057. [CrossRef]

57. Yu, Q.-h.; Wang, B.; Li, N.; Tang, Y.; Yang, S.; Yang, T.; Xu, J.; Guo, C.; Yan, P.; Wang, Q. CRISPR/Cas9-induced targeted mutagenesis and gene replacement to generate long-shelf life tomato lines. Sci. Rep. 2017, 7, 11874. [CrossRef]

58. Li, R.; Li, R.; Li, X.; Fu, D.; Zhu, B.; Tian, H.; Luo, Y.; Zhu, H. Multiplexed CRISPR/Cas9-mediated metabolic engineering of $\gamma$-aminobutyric acid levels in Solanum lycopersicum. Plant Biotechnol. J. 2018, 16, 415-427. [CrossRef]

59. Abe, A.; Kosugi, S.; Yoshida, K.; Natsume, S.; Takagi, H.; Kanzaki, H.; Matsumura, H.; Yoshida, K.; Mitsuoka, C.; Tamiru, M. Genome sequencing reveals agronomically important loci in rice using MutMap. Nat. Biotechnol. 2012, 30, 174. [CrossRef]

60. Garcia, V.; Bres, C.; Just, D.; Fernandez, L.; Tai, F.W.J.; Mauxion, J.-P.; Le Paslier, M.-C.; Bérard, A.; Brunel, D.; Aoki, K. Rapid identification of causal mutations in tomato EMS populations via mapping-by-sequencing. Nat. Protoc. 2016, 11, 2401. [CrossRef]

61. Sánchez-Martín, J.; Steuernagel, B.; Ghosh, S.; Herren, G.; Hurni, S.; Adamski, N.; Vrána, J.; Kubaláková, M.; Krattinger, S.G.; Wicker, T. Rapid gene isolation in barley and wheat by mutant chromosome sequencing. Genome Biol. 2016, 17, 221. [CrossRef] [PubMed]

62. Shirasawa, K.; Fukuoka, H.; Matsunaga, H.; Kobayashi, Y.; Kobayashi, I.; Hirakawa, H.; Isobe, S.; Tabata, S. Genome-wide association studies using single nucleotide polymorphism markers developed by re-sequencing of the genomes of cultivated tomato. DNA Res. 2013, 20, 593-603. [CrossRef]

63. Koornneef, M.; Bosma, T.; Hanhart, C.; Van der Veen, J.; Zeevaart, J. The isolation and characterization of gibberellin-deficient mutants in tomato. Theor. Appl. Genet. 1990, 80, 852-857. [CrossRef]

64. Koornneef, M.; Bade, J.; Hanhart, C.; Horsman, K.; Schel, J.; Soppe, W.; Verkerk, R.; Zabel, P. Characterization and mapping of a gene controlling shoot regeneration in tomato. Plant J. 1993, 3, 131-141. [CrossRef]

65. Van Tuinen, A.; Hanhart, C.J.; Kerckhoffs, L.H.J.; Nagatani, A.; Boylan, M.T.; Quail, P.H.; Kendrick, R.E.; Koornneef, M. Analysis of phytochrome-deficient yellow-green-2 and aurea mutants of tomato. Plant J. 1996, 9, 173-182. [CrossRef]

66. Thompson, A.J.; Tor, M.; Barry, C.S.; Vrebalov, J.; Orfila, C.; Jarvis, M.C.; Giovannoni, J.J.; Grierson, D.; Seymour, G.B. Molecular and genetic characterization of a novel pleiotropic tomato-ripening mutant. Plant Physiol. 1999, 120, 383-390. [CrossRef] [PubMed]

67. Ronen, G.; Carmel-Goren, L.; Zamir, D.; Hirschberg, J. An alternative pathway to $\beta$-carotene formation in plant chromoplasts discovered by map-based cloning of Beta and old-gold color mutations in tomato. Proc. Natl. Acad. Sci. USA 2000, 97, 11102-11107. [CrossRef] [PubMed]

68. Barry, C.S.; McQuinn, R.P.; Thompson, A.J.; Seymour, G.B.; Grierson, D.; Giovannoni, J.J. Ethylene insensitivity conferred by the Green-ripe and Never-ripe 2 ripening mutants of tomato. Plant Physiol. 2005, 138, 267-275. [CrossRef] [PubMed]

69. Manning, K.; Tör, M.; Poole, M.; Hong, Y.; Thompson, A.J.; King, G.J.; Giovannoni, J.J.; Seymour, G.B. A naturally occurring epigenetic mutation in a gene encoding an SBP-box transcription factor inhibits tomato fruit ripening. Nat. Genet. 2006, 38, 948. [CrossRef]

70. Barry, C.S.; McQuinn, R.P.; Chung, M.-Y.; Besuden, A.; Giovannoni, J.J. Amino acid substitutions in homologs of the STAY-GREEN protein are responsible for the green-flesh and chlorophyll retainer mutations of tomato and pepper. Plant Physiol. 2008, 147, 179-187. [CrossRef]

71. Kang, J.-H.; Liu, G.; Shi, F.; Jones, A.D.; Beaudry, R.M.; Howe, G.A. The tomato odorless-2 mutant is defective in trichome-based production of diverse specialized metabolites and broad-spectrum resistance to insect herbivores. Plant Physiol. 2010, 154, 262-272. [CrossRef] [PubMed]

72. Barry, C.; Aldridge, G.M.; Herzog, G.; Ma, Q.; McQuinn, R.P.; Hirschberg, J.; Giovannoni, J.J. Altered chloroplast development and delayed fruit ripening caused by mutations in a zinc metalloprotease at the lutescent 2 locus of tomato. Plant Physiol. 2012, 159, 1086-1098. [CrossRef] 
73. Nadakuduti, S.S.; Pollard, M.R.; Kosma, D.K.; Allen, C.; Ohlrogge, J.; Barry, C. Pleiotropic phenotypes of the sticky peel (pe) mutant provide new insight into the role of CUTIN DEFICIENT 2 in epidermal cell function in tomato. Plant Physiol. 2012, 159, 945-960. [CrossRef] [PubMed]

74. Petit, J. Identification et Validation Fonctionnelle de gènes Candidats Contrôlant la Composition de la Cuticule chez le Fruit de tomate. Université Sciences et Technologies-Bordeaux I, 2013. Available online: https://www.theses.fr/2013BOR15225 (accessed on 17 December 2013).

75. Ariizumi, T.; Kishimoto, S.; Kakami, R.; Maoka, T.; Hirakawa, H.; Suzuki, Y.; Ozeki, Y.; Shirasawa, K.; Bernillon, S.; Okabe, Y. Identification of the carotenoid modifying gene PALE YELLOW PETAL 1 as an essential factor in xanthophyll esterification and yellow flower pigmentation in tomato (Solanum lycopersicum). Plant J. 2014, 79, 453-465. [CrossRef] [PubMed]

76. Kang, J.-H.; McRoberts, J.; Shi, F.; Moreno, J.; Jones, D.; Howe, G.A. The flavonoid biosynthetic enzyme chalcone isomerase modulates terpenoid production in glandular trichomes of tomato. Plant Physiol. 2014, 164, 1161-1174. [CrossRef]

77. Neuman, H.; Galpaz, N.; Cunningham Jr, F.X.; Zamir, D.; Hirschberg, J. The tomato mutation nxd1 reveals a gene necessary for neoxanthin biosynthesis and demonstrates that violaxanthin is a sufficient precursor for abscisic acid biosynthesis. Plant J. 2014, 78, 80-93. [CrossRef] [PubMed]

78. Shikata, M.; Ezura, H. Micro-Tom Tomato as an Alternative Plant Model System: Mutant Collection and Efficient Transformation. In Plant Signal Transduction; Humana Press: New York, NY, USA, 2016; pp. 47-55.

79. Ariizumi, T.; Aoki, K.; Ezura, H. Systematic development of tomato bioresources in Japan. Interdiscip. Bio Cent. 2011, 3, 1-7. [CrossRef]

80. Saito, T.; Ariizumi, T.; Okabe, Y.; Asamizu, E.; Hiwasa-Tanase, K.; Fukuda, N.; Mizoguchi, T.; Yamazaki, Y.; Aoki, K.; Ezura, H. TOMATOMA: A novel tomato mutant database distributing Micro-Tom mutant collections. Plant Cell Physiol. 2011, 52, 283-296. [CrossRef] [PubMed]

(C) 2019 by the authors. Licensee MDPI, Basel, Switzerland. This article is an open access article distributed under the terms and conditions of the Creative Commons Attribution (CC BY) license (http://creativecommons.org/licenses/by/4.0/). 